\title{
KAIMEAR ISLAND ROCK ART SITE AT KUR ISLAND IN WEST KEI ISLANDS REGION, A NEW DISCOVERY IN EASTERN INDONESIA
}

\author{
Wuri Handoko ${ }^{1 *}$, Godlief Arsthen Peseletehaha ${ }^{1}$, Andrew Huwae ${ }^{1}$, Tofan Gayum Rumaf ${ }^{2}$ \\ ${ }^{1}$ Balai Arkeologi Maluku \\ J1. Namalatu-Latuhalat, Ambon 97118, Indonesia \\ ${ }^{2}$ Universitas Pattimura \\ J1. Ir. M. Putuhena, Ambon 97233, Indonesia \\ *wuri.handoko@kemdikbud.go.id
}

Received: 30/09/2018; revisions: 02/11 - 10/12/2018; accepted: 12/12/2018

Published online: $31 / 12 / 2018$

\begin{abstract}
The Rock art site on Kaimear Island, the Kur Islands in the Kei Islands region was for the first time recorded and reported by the Balai Arkeologi Maluku Research Team in 2018. Archaeologists have never recorded and reported any rock art site on Kaimear Island before. The discovery of Kaimear's rock art adds to the rock art sites in Maluku, which were previously reported by archaeologists from outside the country. This study uses a qualitative descriptive approach based on archaeological research through surveys and observations supported by literature studies. It is also exploratory research that follows up information from local communities. Data collection for this study consisted of taking images of a number of rock art panels and field notes containing a brief description. Rock art on Kaimear Island includes many panels of rock art, with the number of images estimated at 400-500 patterns in a steep rocky niche location. In addition to human figure shapes in various styles, there are also hand stencils, foot stencils, boats, animals, circles, and many other unidentified images. The results of the study establish the importance of the discovery of this site, and that it is necessary to follow up with more systematic and intensive research to support the preservation of the site in the future.
\end{abstract}

Keywords: rock art; prehistoric; Kaimear; Kei Islands; Maluku

\section{INTRODUCTION}

In an archaeological survey conducted by the research team of Balai Arkeologi Maluku in early September 2018, the discovery was made of rock art on Kaimear Island, located in the Kur Islands region which is part of the Kei Islands. Kaimear Island is included in the administrative area of the Kur Island, Tual City. From the sea view, there is a landscape with karst topography and the island morphology, which contains many caves. This confirms the description of rock art according to information from the community and also the Head of the Kur Islands as images on the cliff wall on the coast, located nearby Kaimear Village on Kaimear Island, which is one of several small islands in the Kur Islands District.

The people of Kaimear Island were previously aware of the existence of rock art on rock cliffs on the island, although they did not know its importance in revealing past cultural expressions. Although it is nothing new to the local community, in the archaeological research record, Kaimear Island's rock art site is a new discovery, first reported by Balai Arkeologi Maluku. The existence of rock art sites on Kaimear Island adds to the number of rock art that previously discovered and reported on by foreign archaeologists who have studied in Maluku.

Röder, (1938), first reported the existence of rock art on Seram Island where he conducted research in the Saleman Gulf, North Seram and around the Tala River, West Seram. The research conducted by Röder was part of Frobenius's expedition carried out in 1937 to 1938 (Ririmasse, 2007; Röder, 1938). In the Saleman Gulf, Röder discovered rock art with a human holding a shield on his left hand, patterns of hand stencils, lizards, birds, the sun, and boats. During his research conducted around the Tala River, Röder discovered rock art with human figures, deer, birds, boats, circles and sun motifs. Since then no other archaeological researchers have further investigated Röder's discovery of rock art sites on the 
Tala River. Ballard (1988), has reported the existence of rock art in the Kei Islands region, precisely in the Ohoidertawun Village area, on Small Kei Island. Ballard called the rock art site as Dudumahan, which according to him is the name of a former village located above the site complex (Ballard, 1988: 139; Ririmasse, 2007). In a later research report, Intan and Istari (1995), named the site complex as Loh Vat, according to the name of the cave in the complex (Ballard mentioned the name of the cave as Luat). Intan also gave the name Dudumahan as Ballard did, but Dudumahan in Intan and Istari's report refers specifically to the spring near the site complex (Intan \& Istari, 1995: 19; Ririmasse, 2007).

Ballard (1988: 140) in his study also stated that there was a rock art site called Matgugul Kakun on the South Coast of Buru Island. Whether this site is the same as one Suryanto referred to in Wifata or it is a different site, requires further study in the future. Another rock art site in Maluku, which has been almost ignored in various rock art studies, is the Wifata site in the southern part of Buru Island. This site has the form of a niche on the shoreline with a height of about 20 meters above sea level and was first discovered in a study that the Balai Arkeologi Ambon conducted in 1997. The motifs found on this Wifata site are hand stencils, humans, wind, boats, and geometrical shapes (rhombus) (Ririmasse, 2007; Suryanto, 1997). In the context of local rock art, Balai Arkeologi Maluku classifies the type as the Wamkana rock art pattern, which consists of humans dancing, hand stencils, a spherical wind direction, boats, fish, vertical lines, and geometrical motifs (Ririmasse, 2007; Salhuteru, 2009).

In the wider region, rock art is found in the Maros karst region in South Sulawesi, Muna Island in Southeast Sulawesi (Kosasih, 1999), as well as Berau Bay, Triton, and Lake Sentani in Papua, which Arifin (1992) and Wright et al. (2013) have reviewed. Around 1994, Fage together with Chazine found a rock art site with hematite red pigment patterns in Sangkulirang, East Kalimantan. Again, in 1995 and 2002, Fage \& Chazine (2009) together with Pindi discovered another site complex that featured rock art in the same area. The discoveries were further investigated in 2005-2007 in an archaeological research collaboration between Indonesia and France. The assumption of a single rock art style in Eastern Indonesia has been abandoned (Oktaviana et al., 2016: 273; Simanjuntak \& Oktaviana, 2012). In greater detail, Adhi Agus Oktaviana (2016) discussed rock art sites throughout Indonesia. Rock art in Indonesia found in caves, niches, and coral cliffs throughout the Indonesian karst region. Rock art sites spread from the farthest eastern part of Indonesia, including the Papua region, such as the Berau Bay, Kaimana, Triton Bay karst area (Arifin \& Delanghe, 2004; Gonthier, Budiman, Djami, \& Simanjuntak, 2013; Röder, 1938), Lake Sentani (Arifin \& Delanghe, 2004), South Misool (Sulistyarto et al., 2014), Dudumahan karst area in the Kei Islands, and the southeastern part of Seram Island (Ballard, 1988;

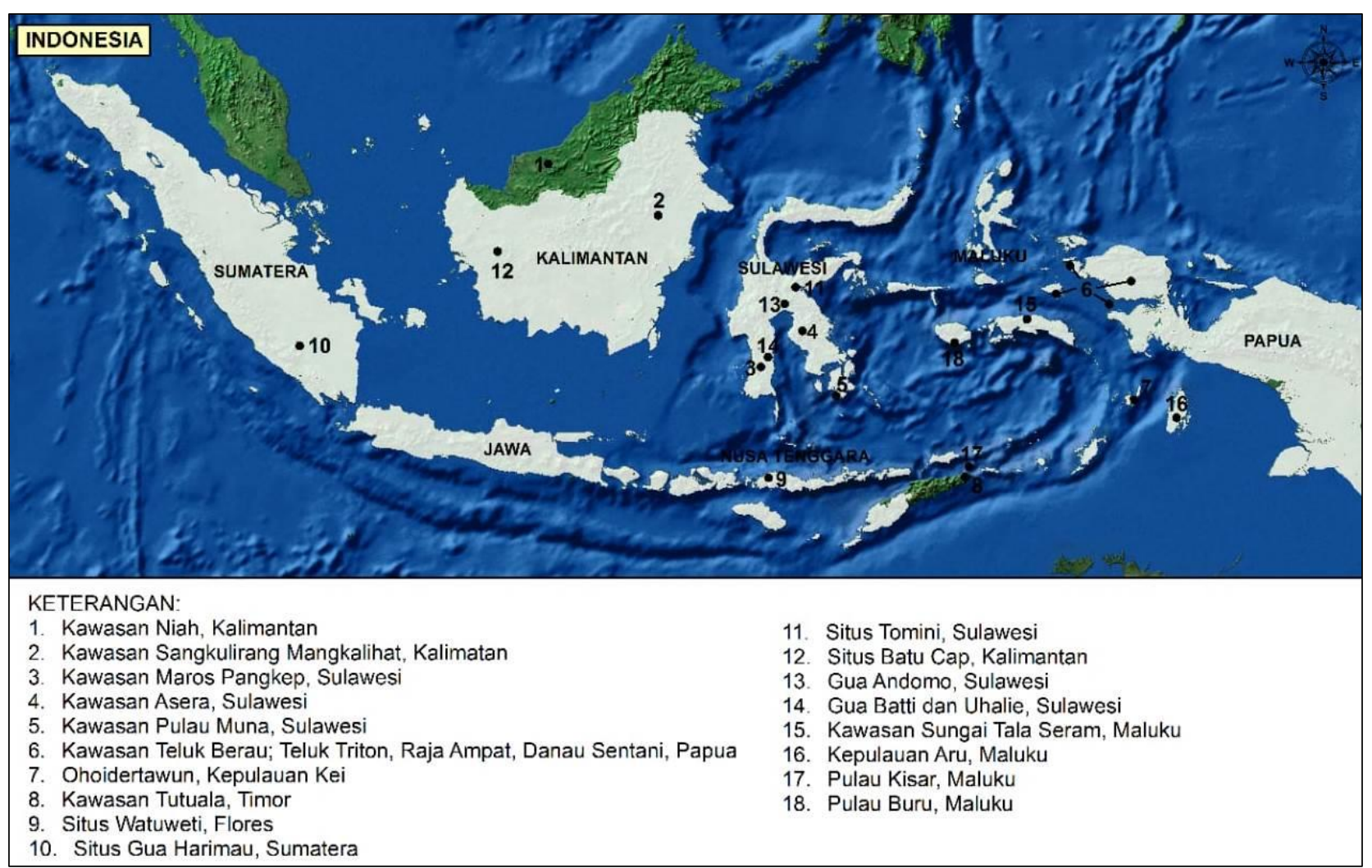

Figure 1. Map of the distribution of Rock Art Site Areas throughout the Indonesian Archipelago based on published research, modified by the Authors

Source: Adhi Agus Oktaviana, et al., 2016 
Setiawan, 1994). In the Maluku region, the most recent discovery of rock art was reported by O'Connor et al. (2017) in an archaeological study on Kisar Island. O'Connor et al. (2017) reported that rock art discoveries have been recorded in at least 28 caves on Kisar Island and estimated that rock art has existed there since the Neolithic era and d in the early Bronze Age about 2500 years ago. At almost the same time Peter Lape (2017) found rock art sites in Seram Timur (Seram Laut) (Lape et al., 2017: 69; A. A. Oktaviana, Lape, \& Ririmasse, 2016).

In the Central Indonesia region, there is a karst area in Nusa Tenggara Timur which is known to have a distribution of rock art, which is in Tanjung Tutuala (O'Connor, 2003) the nation of Timor Leste and the latest find is the discovery of rock art sites in Kupang in West Timor (O’Connor, Louys, Kealy, \& Mahirta, 2015). The distribution of rock art sites in Sulawesi includes the Maros-Pangkep karst area, and Bone karst area (Adi Agus Oktaviana et al., 2016; Aubert et al., 2014; Permana, 2005), as well as the Lake Towuti (Adi Agus Oktaviana et al., 2016) karst area, Morowali area, and Matarombeo karst area (Fage, 2014). Initially, the archaeological team aimed to carry out Islamic archaeology research in the Kei Islands region. The Kur Islands are the farthest western region in the Kei Islands and border the Gorom islands area in Seram Timur. In this paper, we aim to publish information and preliminary descriptions of panels of rock art discovered along the recesses of rock cliffs on the Shore of Kaimear Island.

\section{MethodS}

This paper uses a qualitative descriptive approach based on archaeological research through surveys and observations, supported by literature studies. It is very much exploratory research, considering that the site area had never been studied before. Exploratory research means a study based on the absence of archaeological investigations ever conducted in the research area (see (Bhattacherjee, 2012, 6-10; Fauzi, 2016: 3-4). Given the

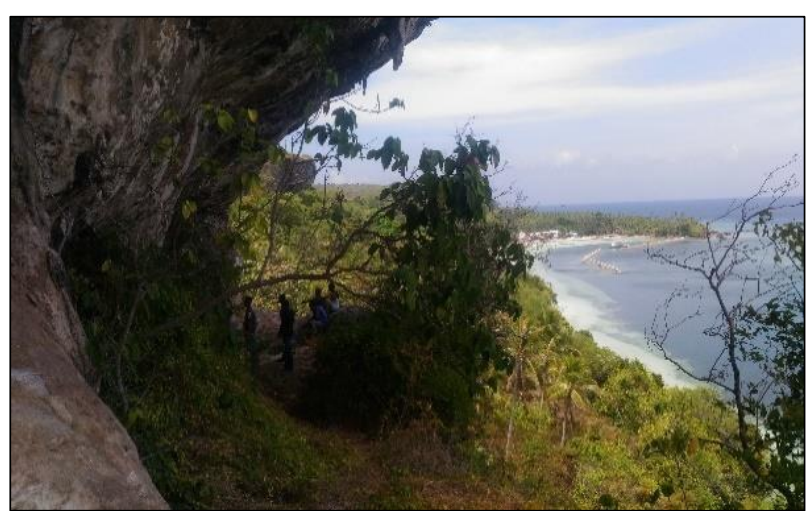

limited knowledge of the author about rock art, the description is focused on the results of eyesight observation. Nonetheless, in order to clarify rock art in its visualization, the author used the D'stretch application to clarify some images where it is difficult to identify the shape of the pattern or figure.

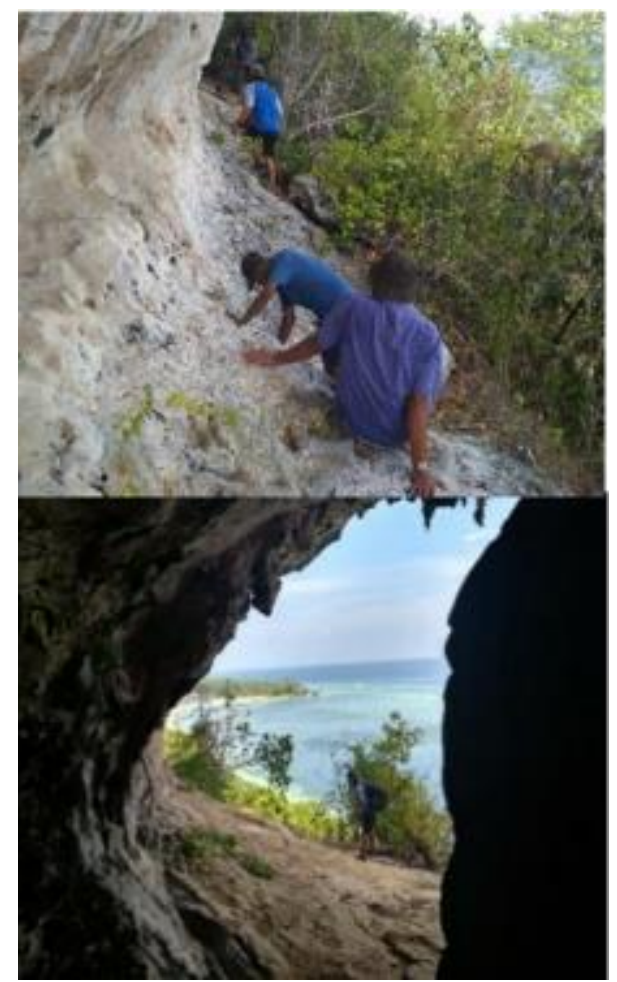

Figure 2. The Research Team was conducting observations on the Kaimear Island Rock art site. The steep slope conditions of the niche floor and the minimum safety standards require the team members to be extremely cautious Source: Balai Arkeologi Maluku, 2018

\section{RESULT AND DISCUSSION}

\section{Profile of Kaimear Island and Prehistoric Archaeological Potential}

Kaimear Island is a relatively small island, with a size of $3.32 \times 1.52 \mathrm{~km}$ and a total area of $8.32 \mathrm{~km} 2$. The island is located in the western part of the Kei Islands, bordering the Kei Islands and the Gorom Islands to the west. The distance from Kei Kecil Island is $105 \mathrm{~km}$, and it is $141.15 \mathrm{~km}$ to Gorom Island, East Seram Regency.

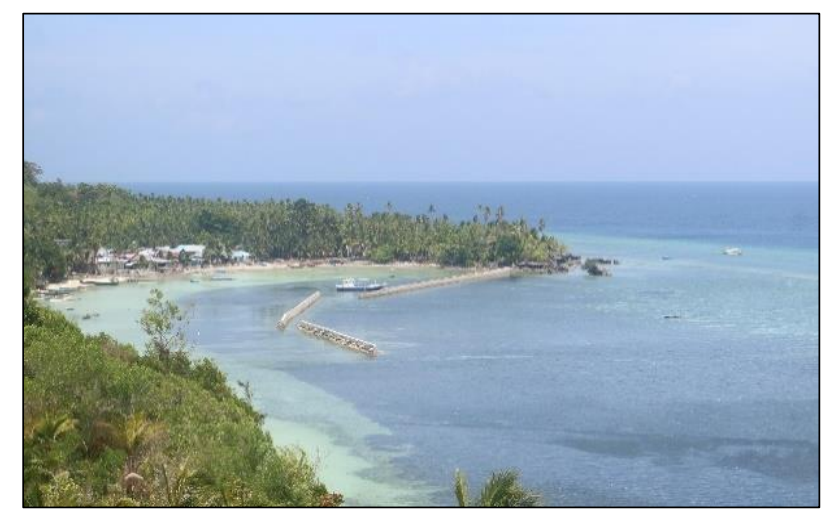

Figure 3. A view of Kaimear Island's coastal landscape from the top of a cliff or a niche in which rock art sites were found Source: Balai Arkeologi Maluku, 2018 

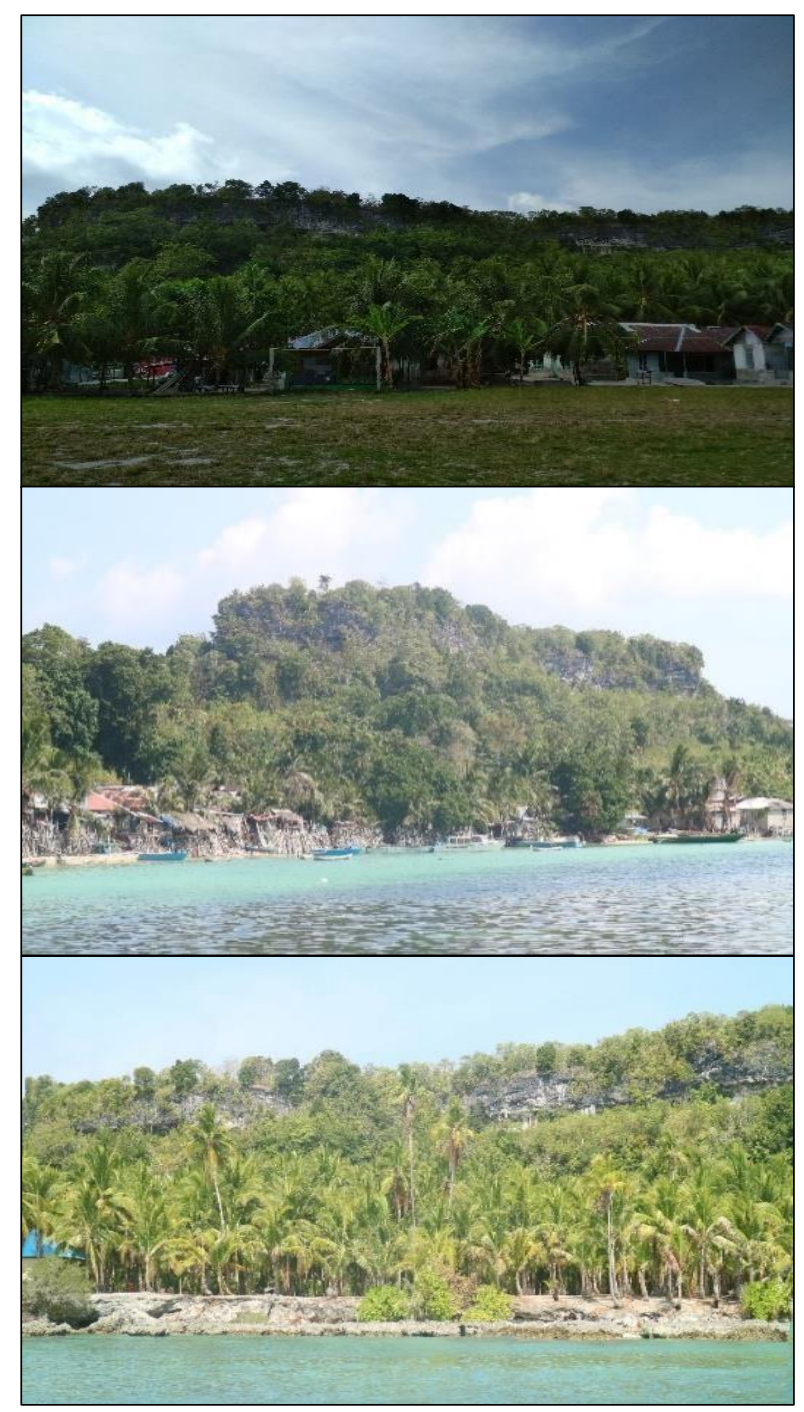

Figure 4. Rows of cliff niches on Kaimear Island that have the potential to provide prehistoric archaeological data Source: Balai Arkeologi Maluku, 2018
Administratively, Kaimear Island is included in the Kur Islands District, Tual City. The distance from the capital of the sub-district on the island of Kur is $20 \mathrm{~km}$, with a travel time of 30 minutes to 1 hour by sea. In order to reach the island, the only transportation that can be used is sea transportation. The trip to the island uses a speedboat taking 3-4 hours from Tual City. The optimum time to reach this island is in the transition months in February-March and October-November, because at that time it is a good season unconstrained by high sea waves. In contrast to those months, sea waves at other times in these waters reach 3-5 meters, conditions that must be avoided to travel to this location. The archaeological research team reached this location using a speedboat from Tayando Island, with a travel time of approximately 2 hours.

The geological conditions of Kaimear Island can be identified based on Indonesian geological maps, Lembar Kai and Tayando 2810 and 2910 with the scale of $1: 250,000$. In general, Kaimear Island is included in the Small Kai geological formation that was formed in the quaternary, with surface sediment in the form of sedimentary rocks $(\mathrm{QK})$, including limestone, reef limestone consisting of coral, mollusks, algae, and Briozoa. Generally, these rocks form low wavy hills, karst fields, and low hills with steep slopes (BPS, 2017). Rock formations of reef limestone dominate lithology on almost all local islands, generally surrounded by coral reefs. This condition allows the existence of coral destruction deposits on the coast around the island. The Coast of Kaimear Island consists of terraces of coral cliffs that have a height of up to 151 meters so that it looks like a large reef fortress viewed from the sea. The
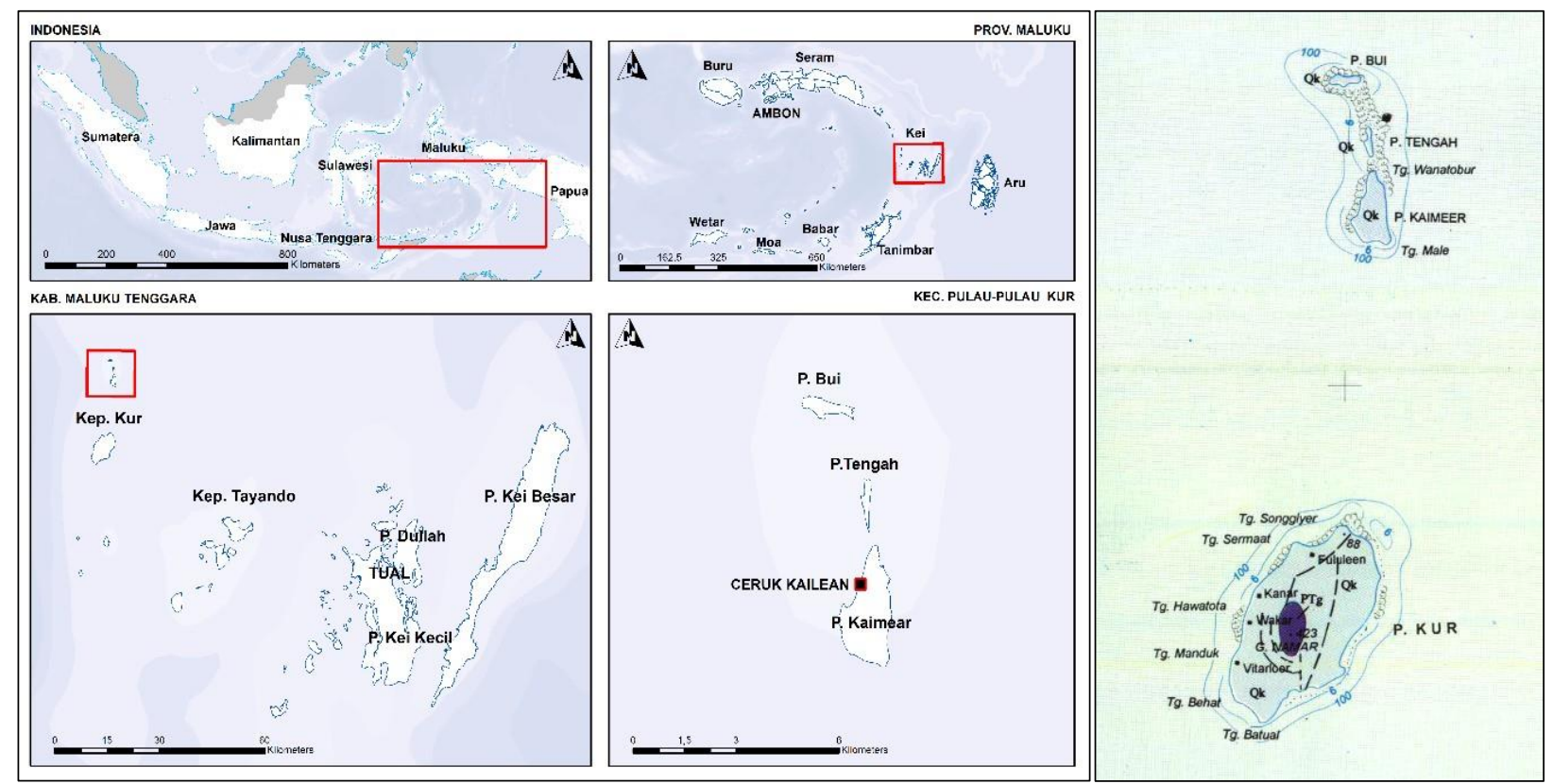

Figure 5. Administrative Map of Research Sites (left); Geological Map of Research Sites as modified according to research needs (right)

Source: Balai Arkeologi Maluku, 2018 


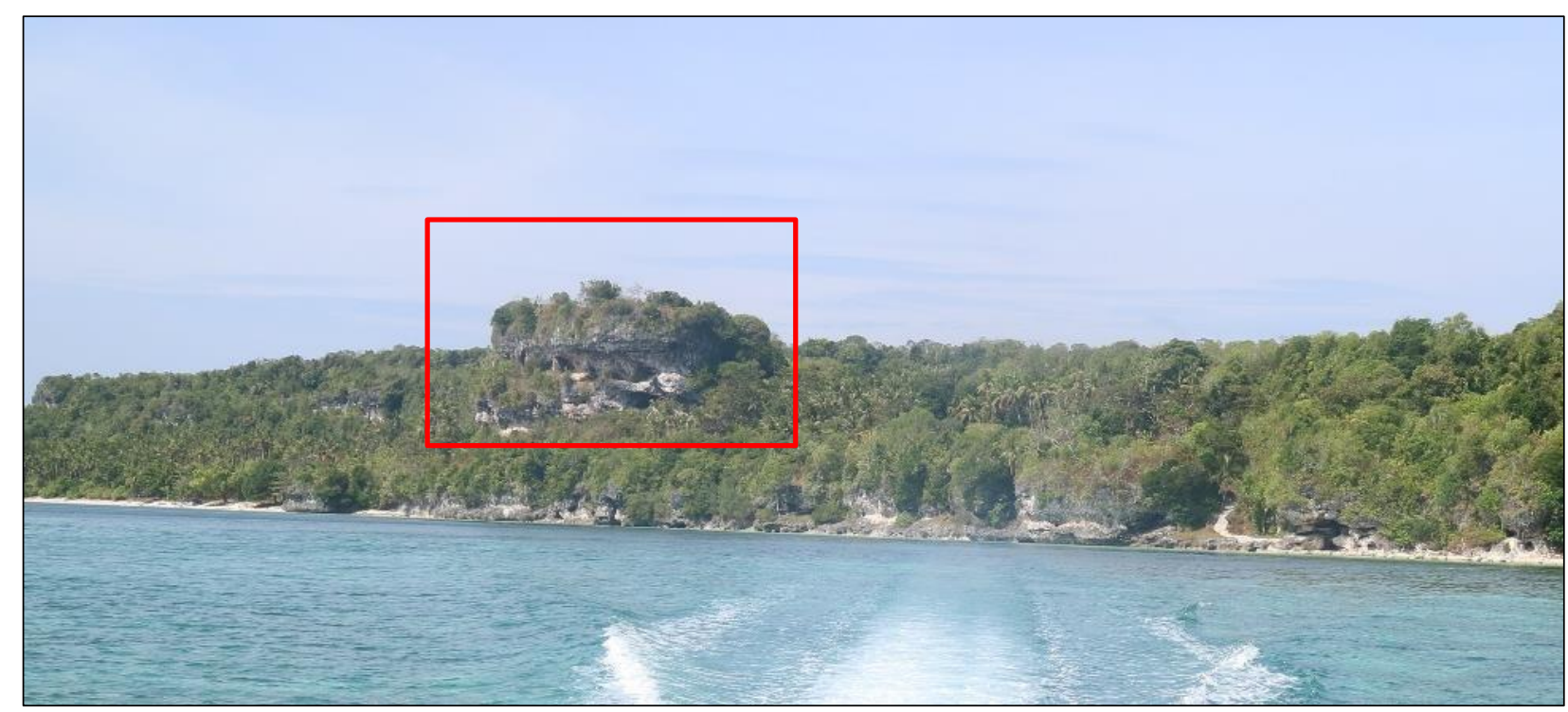

Figure 6. One of the massifs which are the location of the discovery of the rock art site on Kaimear Island Source: Balai Arkeologi Maluku, 2018

southeast side of the island looks like a rocky cliff that emerges from the surface of the sea. From a distance on the wes $t$ side of the island, one can see a village with rows of houses and a small mosque located in the middle of the village. The island has a limited forest area, but there are several coconut plantations on the west coast (NGA, 2018). Considering the many limestone caves found on this island, the local people refer to the Kur Islands as a country of a thousand caves.

Based on the profile of geological conditions and the existence of rock art sites, Kaimear Island has contributed valuable information about the role of small islands in Maluku to reconstruct past cultures in the Maluku Islands region. Information about islands in Maluku was obtained from, among others, (Peter Van Lape, 2000; 2002) who conducted extensive surveys and excavations in the Banda Islands, although most of his research was focused on historical archaeology, while in other islands in Maluku, research in survey and exploration includes research on the Kai Islands (Ballard, 1988; Spriggs \& Miller, 1988), Tanimbar Islands (Ririmasse, 2007; 2010; 2016), Babar Islands (Ririmasse, 2013; Sudarmika, 2000), Leti Islands (Sudarmika, 2001b; Sudarmika, 2001a), and Kisar Island (O’Connor et al., 2017; 2018; Ririmasse, 2006).

In the future, a variety of prehistoric archeological studies can be undertaken in the region, considering that there are sufficiently high indications of archeological potential in prehistoric caves in several locations on Kaimear Island and Kur Island to the east. In the vicinity of Kaimear Village, there are two other uninhabited islands, namely Bui Island and Kanos Island, which are

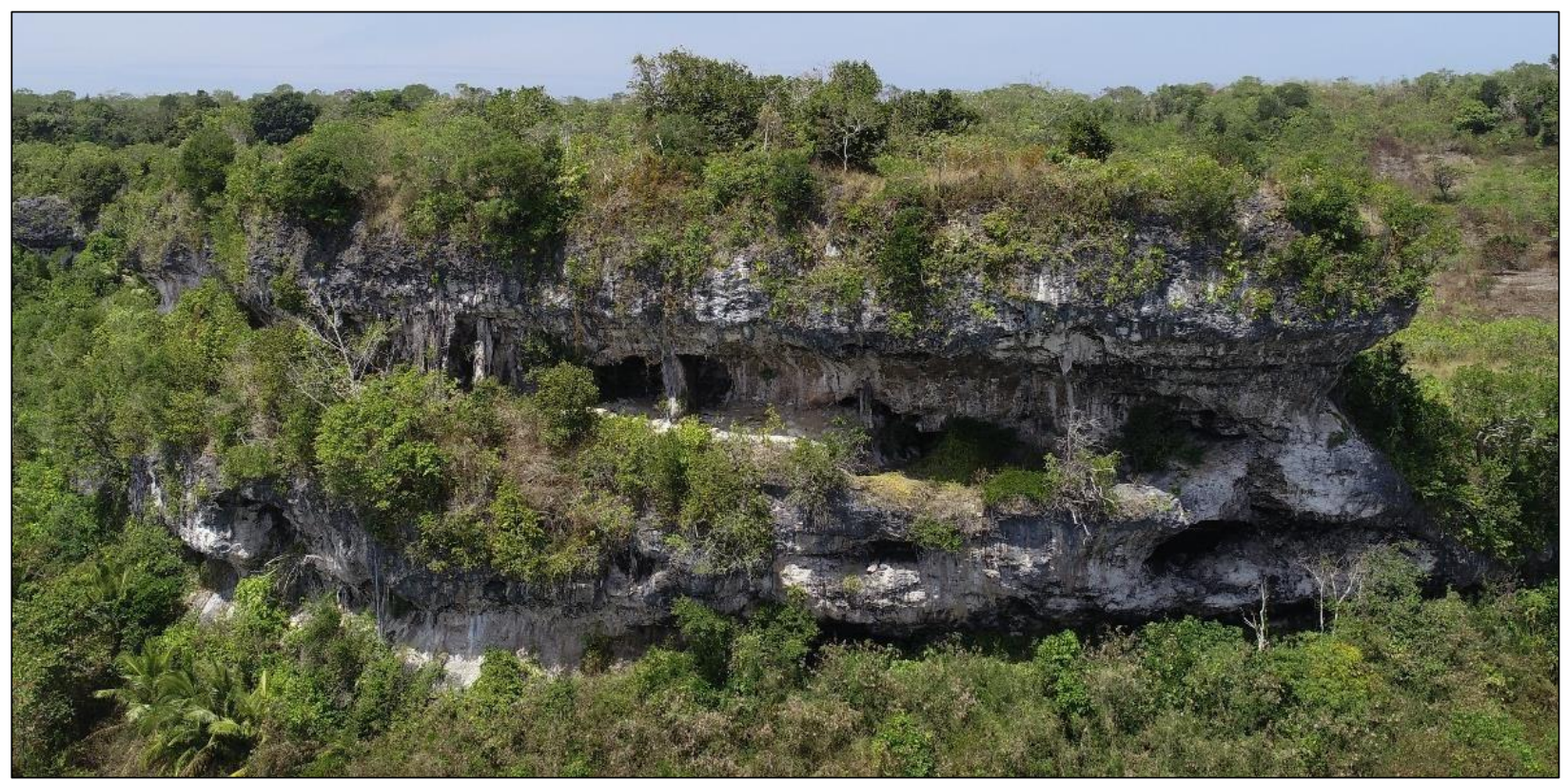

Figure 7. Kailean cave conditions, the location of hundreds of rock art motifs on Kaimear Island, Kur Islands Source: Balai Arkeologi Maluku, 2018 
administratively part of Kaimear Village. We only conducted a limited survey as the provided time did not make it possible to carry out exploratory surveys with a wider reach, and the discoveries of rock art were not our initial target as researchers in Islamic Archaeology. Cave or alcove sites on the Kur and Kaimear Islands in general are niche cliffs jutting out from the land, with steep, relatively high slopes and immediately adjacent to the sea. The height is quite far above the coastline within an extremely high cliff, and so is not easily affected by the process of sea level rise and storm surges. Long-term occupation is therefore likely (Kealy, Wattimena, \& O’Connor, 2018: 4). Meanwhile, many other niches are seen extending along the beach that has not been surveyed. Possibly, these niches contain important prehistoric archaeological data.

\section{Kaimear Island Rock Art Site}

Regardless of its type, consisting of paintings (pictographs) and carvings or petroglyphs, rock art is defined as art in the landscape consisting of drawings, motifs and designs placed on natural and hard surfaces such as cliff walls, large boulders, cave walls and ceilings, and soil surfaces (Leihitu \& Permana, 2018; Setiawan, 2015; Whitley, 2005: 3). Given the limited time for observation, we present initial descriptions of the discoveries of Kaimear Island rock art. In order to assist in the identification of rock art motifs, several images were clarified with the help of the D'stretch application. Among the discoveries of rock art sites in the Maluku Islands, rock art sites on Kaimear Island appear to be the only rock art located on high cliffs (80100 masl) compared to other rock art discoveries. For rock art discoveries on a rock cliff, that on Kaimear Island is the largest regarding quantity and pattern. The quantity of rock art motifs on Kaimear Island is even higher than that recorded by Ballard (1988) at Ohoidertawun, Small Kei Island which consists of about 300 rock art motifs (Ririmasse, 2007). The quantity of rock art in Kaimear Island is estimated to be considerably
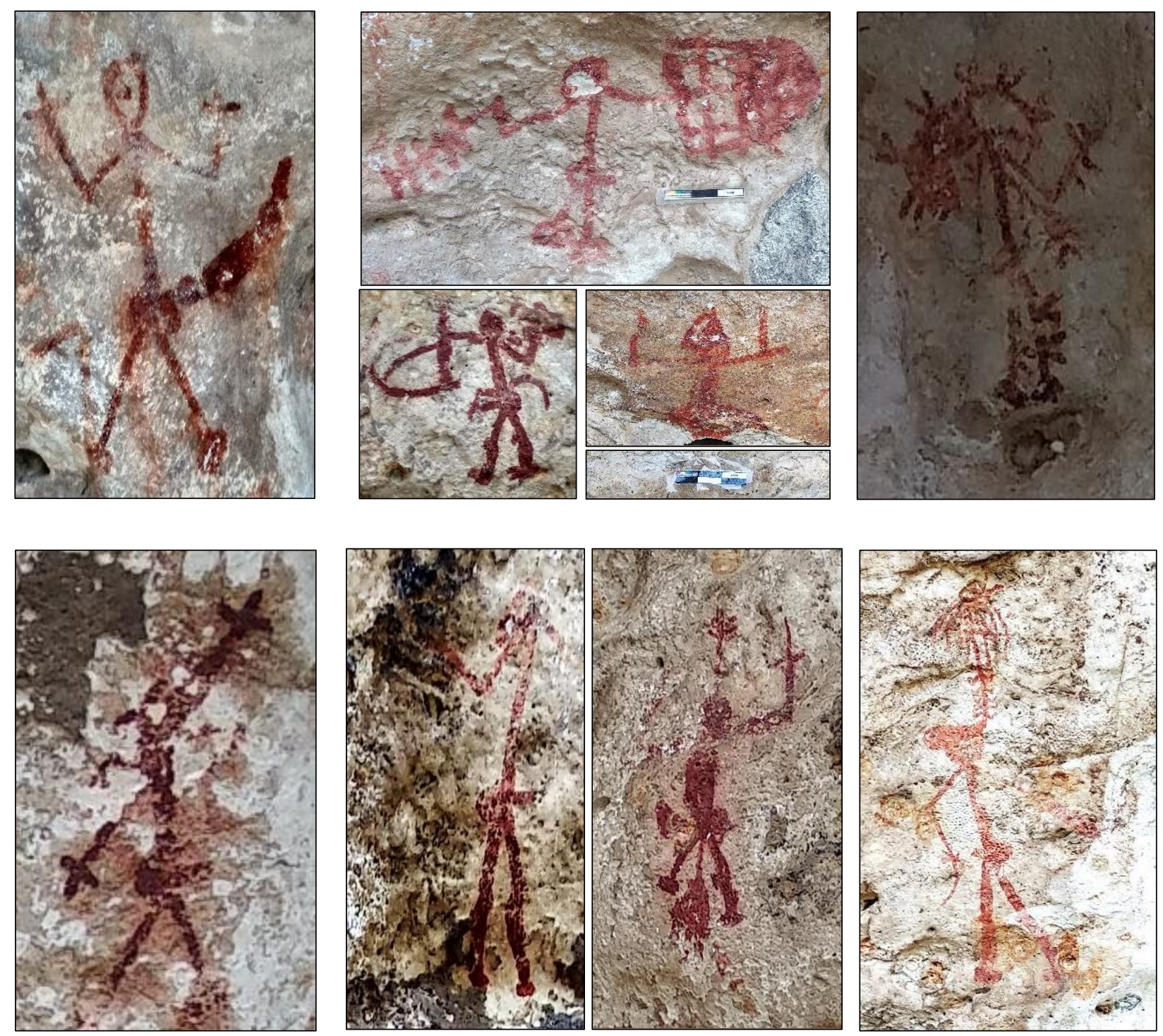

Figure 8. Some rock art forms of human figure motifs in various styles on the rock art site at Kaimear Island, Kur Islands, Kei Islands Region, Maluku

Source: Balai Arkeologi Maluku, 2018 

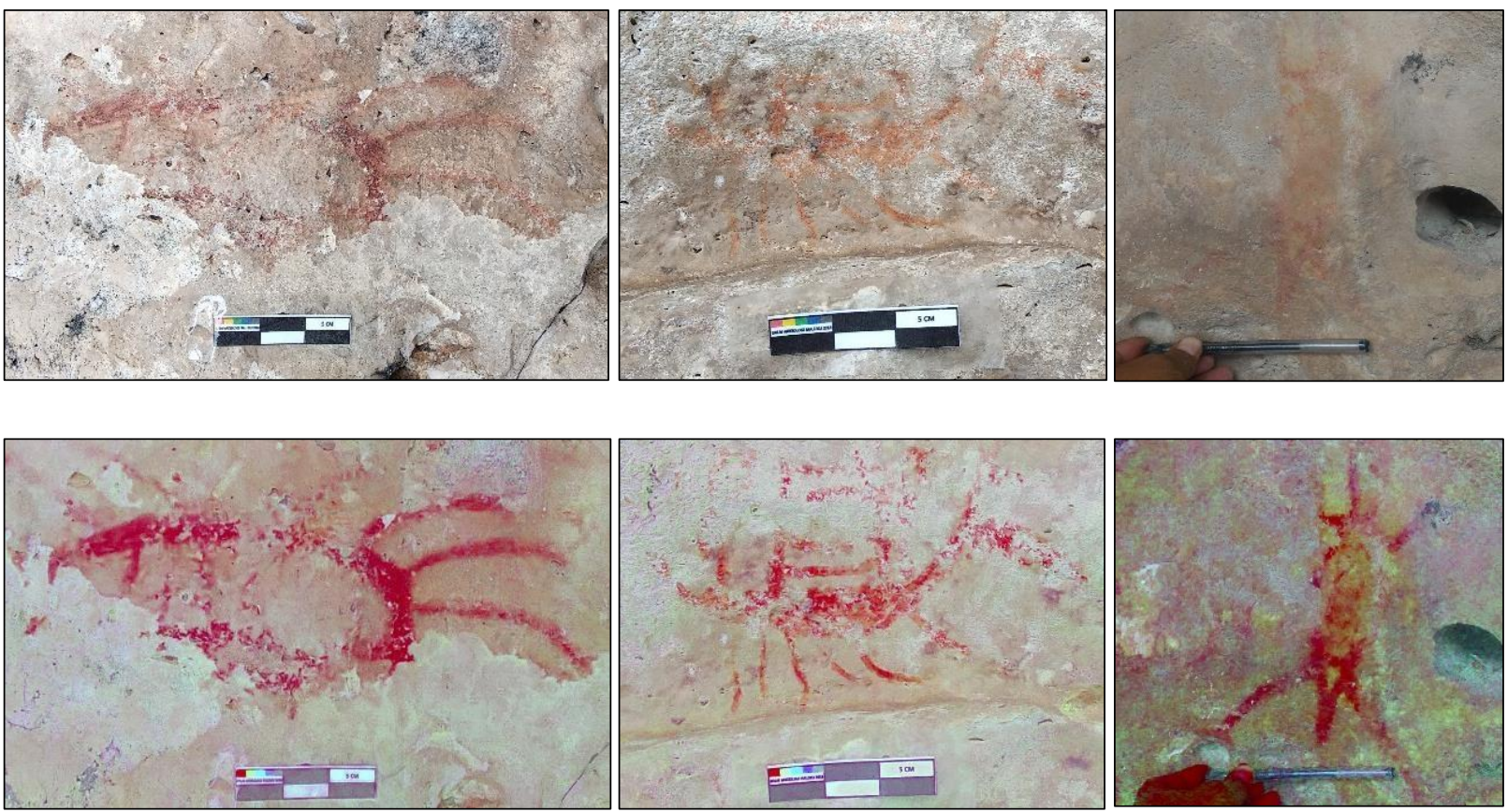

Figure 9. Some rock art motifs of animals at the Rock art site on Kaimear Island Source: Balai Arkeologi Maluku, 2018

more than 500s rock art motifs depicted on rock walls at three location points. As a preliminary illustration, at only one location point, which is in the niche referred to by the community as Gua Kailean, there are likely $400-$ 500 rock art motifs. Rock art on Kaimear Island is at least at three points on a cliff location on the coast. However, this article will describe a rock art site that is considered to represent the most numerous and most diverse motifs, compared to other rock art sites on Kaimear Island.

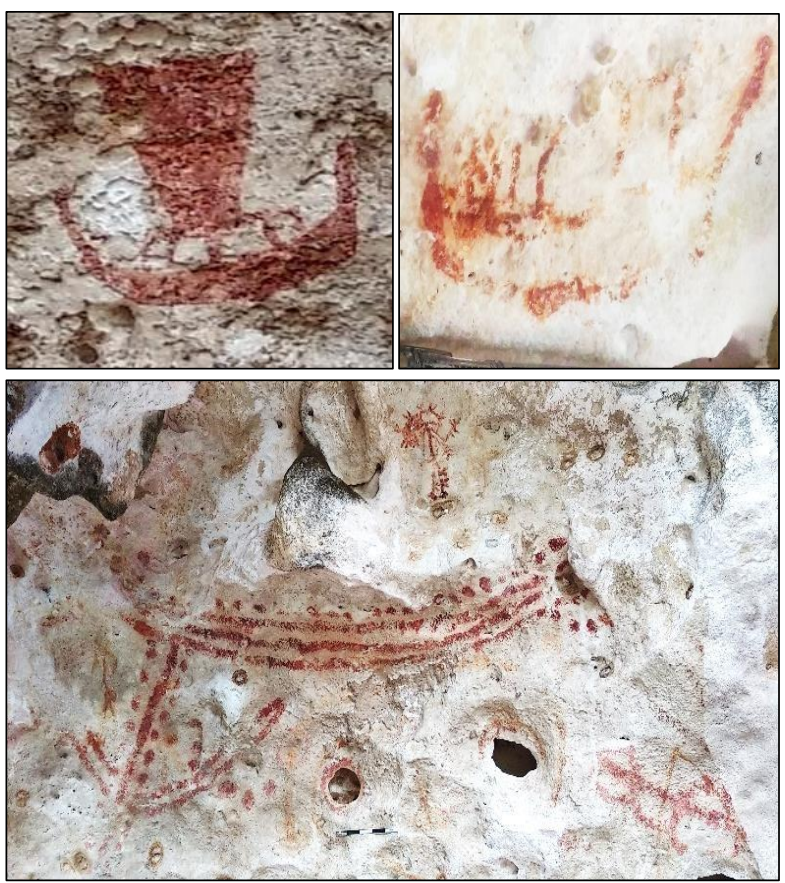

Figure 10. Some boat motifs in the rock art site of Kaimear Island Source: Balai Arkeologi Maluku, 2018

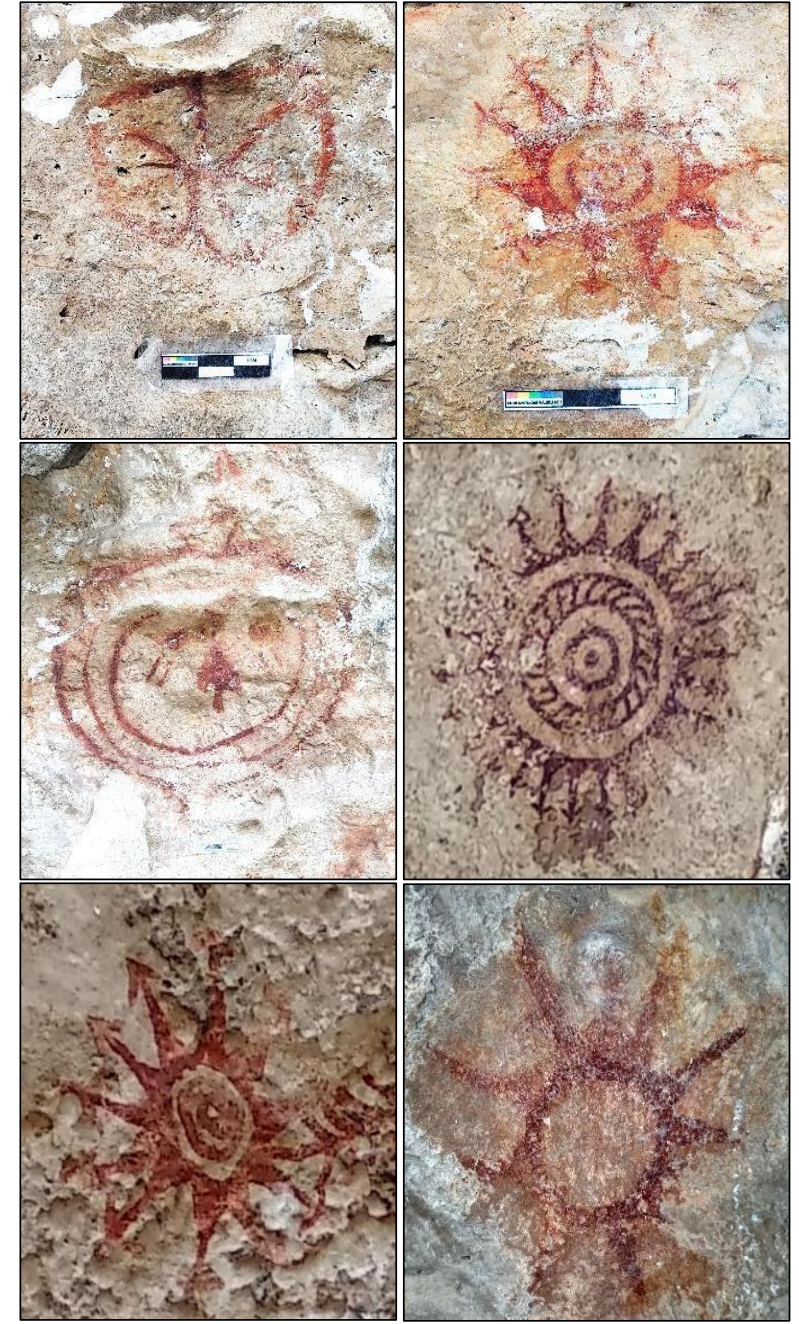

Figure 11. Some circular rock art motifs with various variations on the Rock art island of Kaimear Source: Balai Arkeologi Maluku, 2018 


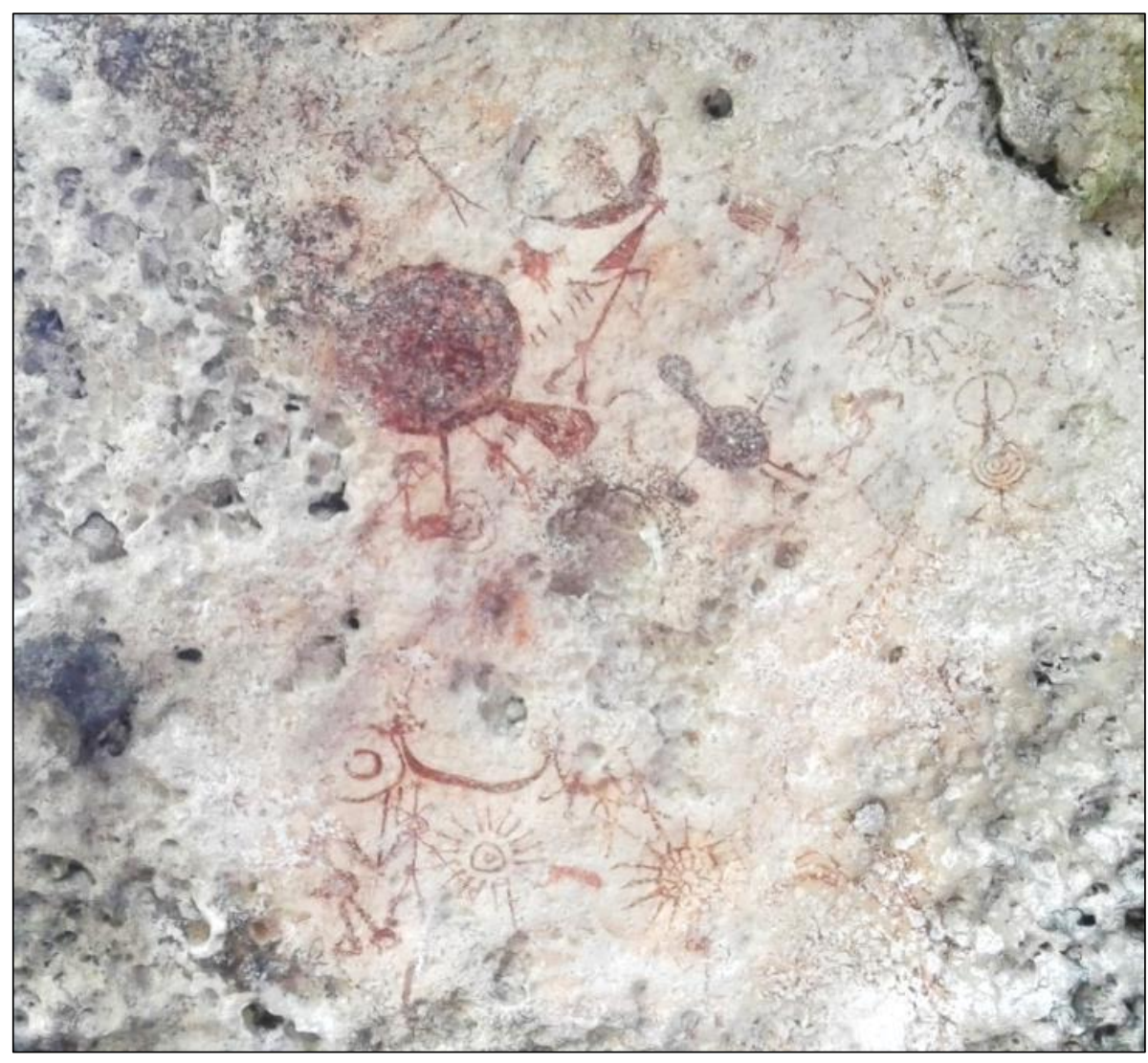

Figure 12. One panel that shows rock art in groups; this rock art is painted on the roof of the niche Source: Balai Arkeologi Maluku, 2018
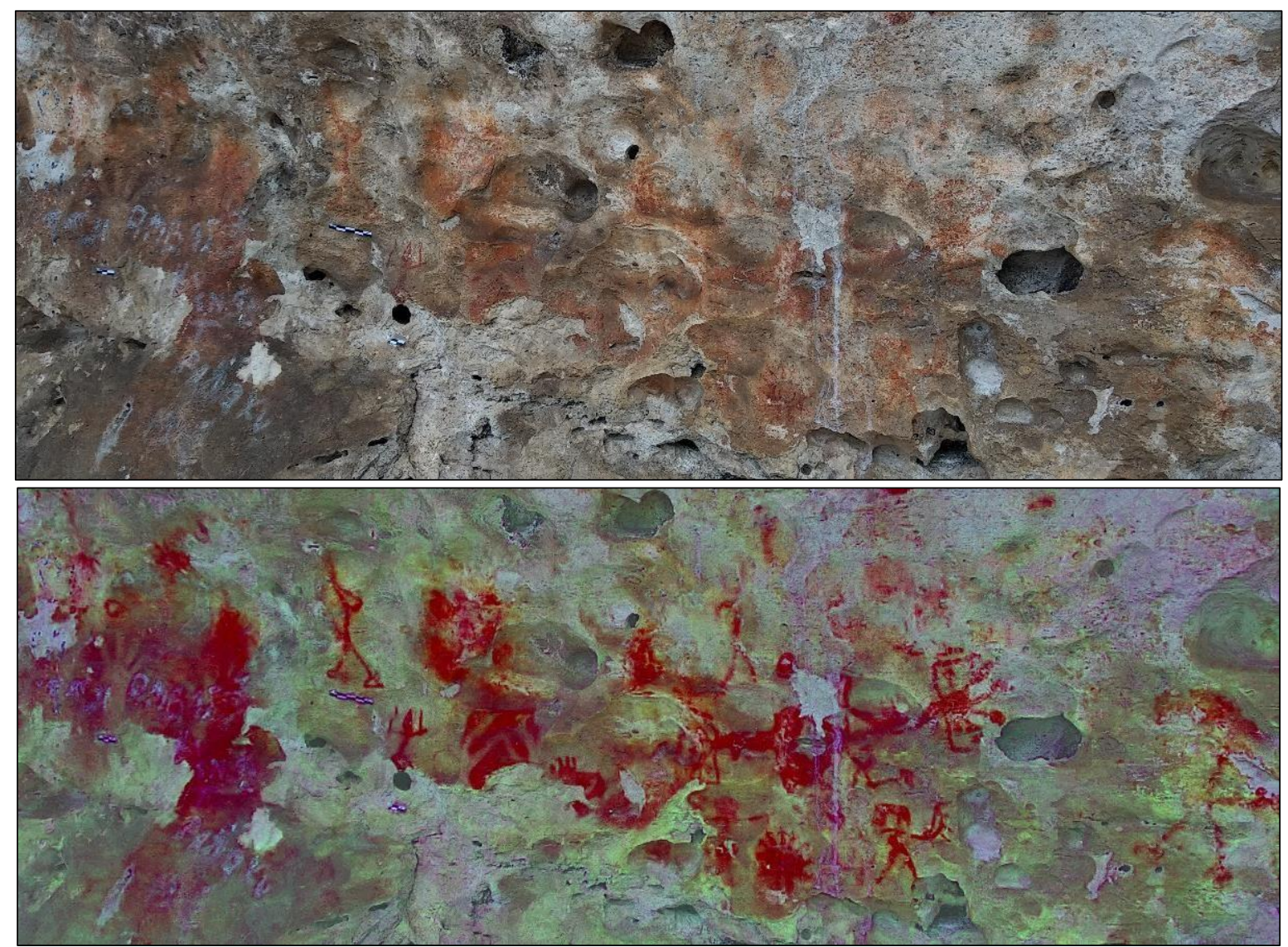

Figure 13. One panel reveals rock art in groups on the wall of the niche (Result of the D'strecht image processing) Source: Balai Arkeologi Maluku, 2018 
The rock art site is located on a niche wall, which is referred to by the community as Kailean Cave or niche, which is in north of Kaimear Village. This site lies on a cliff with a height of 80-100 meters above sea level. From the top of the cliff, there are beautiful beachfront views A description of rock art will be given for a coastal cliff niche, which is about 500 meters from the center of Kaimear Village. In order to reach the niche location one must walk around the back of the cliff and enter from the west. Based on observations and measurements, this niche extends for about $100 \mathrm{~m}$. Much of the rock art was depicted on a part of the niche wall reaching 3 meters high and on the recessed roofs reaching 5-6 meters high from the niche floor. Some rock art was even depicted on the lower wall, almost painted on the cave floor or the lower wall basin leading to the recess/cliff floor.

This rock art includes clearly visible images and unclear images in which the shape is unidentified. The art is very varied in terms of type and shape. Most motifs of the rock art can be identified by their shape and type, and seems dominated by human figure motifs that occupy most of the rock wall panels. Based on our observations, rock art motifs here appear to be divided into two types, which are single and group motifs. The
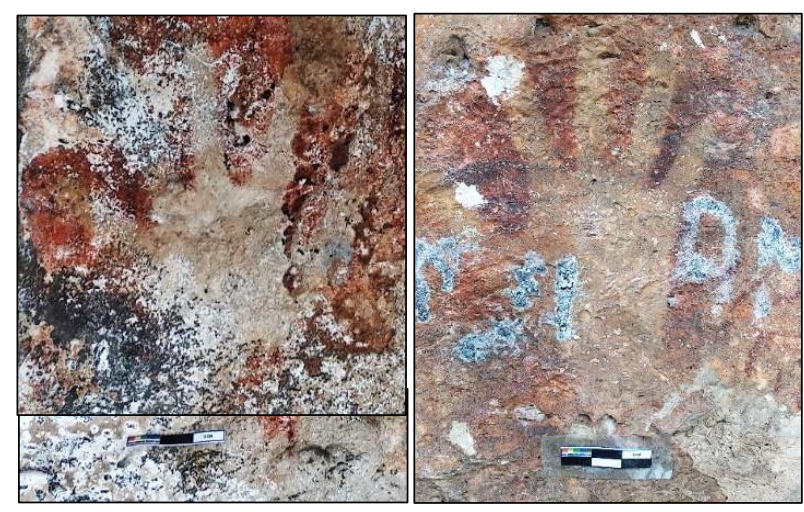

Figure 14. The shape of the hand stencil motif found in the rock art site, Kaimear Island Source: Balai Arkeologi Maluku, 2018

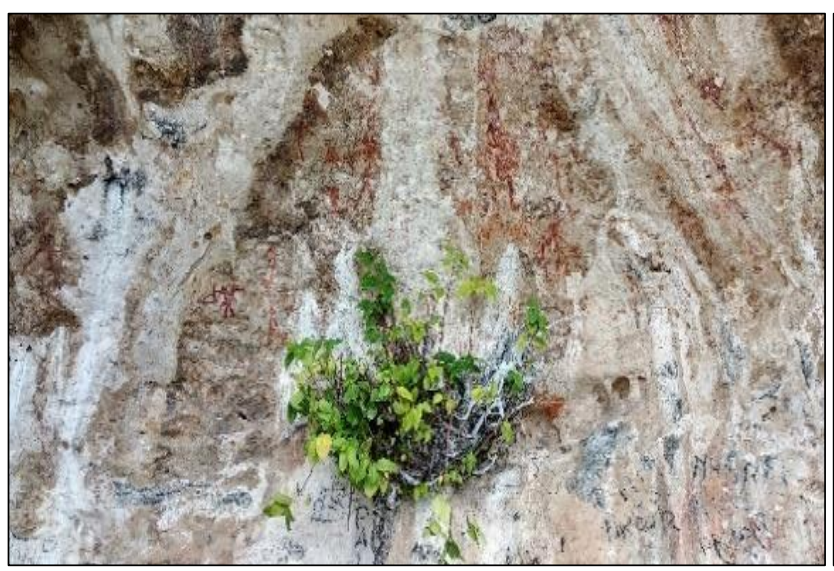

color of rock art generally consists of red and only a small proportion is orange and black. From our observations, the main characteristics indicate that motifs have a striking color, and the pattern is formed by traces of lines or dots forming distinct figures and are not formed by merely striking colors that resemble 'spilled paint' (formless). The rock art motifs of Kaimear Island represent forms that depict figurative and non-figurative shapes. Figurative forms include humans, boats, hand stencils, and animal motifs. Non-figurative forms include line, point, and circle motifs. Human figure motifs consist of ordinary human figures, tall (long) humans, humans carrying equipment (weapons?), humans with a carrying pole, dancing humans, and human faces (round and triangles).

In addition to human figures, Kaimear Island's rock art also displays animal motifs. In general, rock art animal motifs reflect patterns that are difficult to identify, but with the help of the D'stretch application, some motifs that are difficult to identify can now be seen more clearly. There are also some boat motifs, which describe boats with cargo or sails, large boats equipped with anchors and other boat types. In addition to figurative images, there are also many geometric motifs, especially circular ones consisting of the shape of the sun, circle (wheel of life), and so on.

The rock art is generally dominated by grouped image objects, meaning single objects located in clusters. Therefore, such rock art can be seen as a single object or as a group. Group objects are also found on the roof of the niche in addition to the niche walls. There were also some hand stencil motifs. The hand stencil is characterized by a sprinkling of paint coloring around the palm of the hand, while the part covered by the hand is not stained and forms a palm print (Permana, 2005). In addition to the hand stencil motifs, on one of the panels at Kaimear Island's art rock site, one can also identify footprint motifs depicted in grouped objects (see figure $13)$.

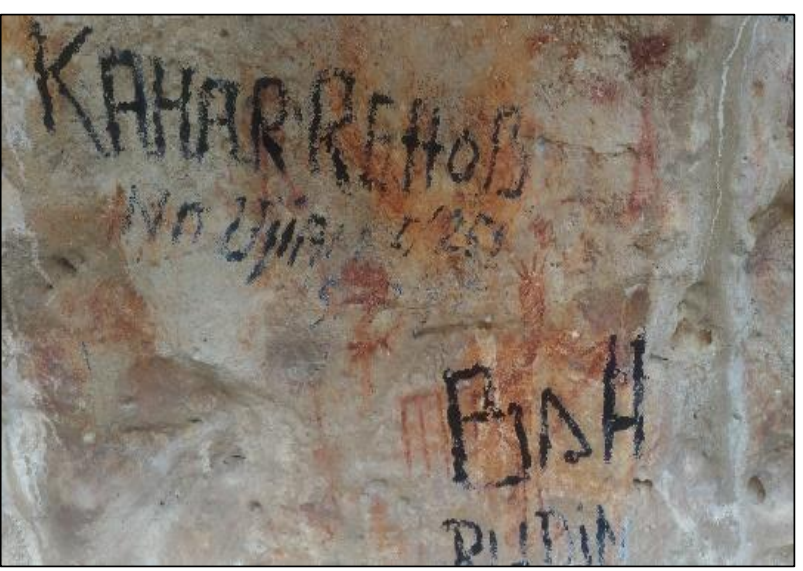

Figure 15. One panel reveals rock art in groups on the walls of a niche threatened by damage from rock weathering, plants on the rock and vandalism

Source: Balai Arkeologi Maluku, 2018 


\section{Vandalism and Threat of Site Damage}

The misunderstanding of the local people concerning the historical significance of rock art makes them indifferent to it. In general, the local population does not consider the rock art important, and they have limited knowledge of its existence or the value of maintaining or preserving it. For local residents, the rock art site is just an exciting place to take a trip.

In some parts of the rock art panel on the niche wall, there are many scribbles (vandalism) performed by local residents when they come to the site. On the west side of the niche, there was more damage to the rock art, marked by the number of faded rock art motifs and the peeling off of rock art color pigments. This is probably due to exposure to direct sunlight, especially during the day and evening.

\section{Rock art and Population Relocation Issues}

In general, the local population considers rock art is "an ancient writing" made during the Dutch Colonial period. 'Their understanding was that the rock art was the result of the actions of the indigenous population who were hiding from the Dutch in the past. Although there is no contextual correlation with the existence of rock art on the island, according to the explanations of the local population, Kaimear Island is considered a "seizure island," an island that was contested to be inhabited or owned by many residents from other tribes from different locations, among others from Papua and even Central Maluku. There is no clear information on why people call it a contested island. Ironically, even until now there is no secure water source on the island. The population makes rainwater storage for every household. Occasionally residents even put fiber boats around their homes as water reservoirs when the rainy season arrives.

The condition of Kaimear Village is classified as remote, distant from the administrative center of Tual City, causing the condition of the village to be isolated and very limited in access to long-distance communication, and with minimal availability of electricity. Population surveys have found no water source This was ironic, considering that the island consists mostly of limestone formations (karst). The lack of availability of water causes conditions in the village to be quite tricky. In order to get water in the rainy season, the residents make rainwater shelters in each house. In the dry season, residents must cross to Kur Island to fetch water, a distance of up to 1 hour by sea on a speedboat. To cross to Kur Island, a distance of $20 \mathrm{~km}$ separated by an open strait, is a challenge, especially in high waves.

There is an ongoing discussion in Tual City concerning the efforts of the Tual City government to relocate people from Kaimear Island. However, the residents of Kaimear Island are unaware of the issue of relocation. In the future, this possibility needs a broader and more serious discussion. However, certainly since the arrival of the archaeological research team of Balai Arkeologi Maluku in early September 2018, the local population considers the rock art site of Kaimear Island as a new hope for the population in the midst of current limitations, as it might be expected to be a focus for tourist development on the island. Rock art is therefore now considered by the local population as a cultural wealth and an critical capital asset for the government's focus on the development of the Kaimear Island community in the future.

\section{CONCluSiON}

The rock art site on Kaimear Island was only discovered by Balai Arkeologi Maluku in early September 2018. The discovery of this rock art site was based on preliminary information from the Head of Kur Islands and local residents, followed up by a limited survey conducted by the research team. Kaimear Island is very rich in rock art, which is painted on rock walls along approximately $100 \mathrm{~m}$, on walls with a height of about 3 meters, while the height of the roof from the floor is about 5 meters. The niche lies at an altitude between 80-100 meters above sea level, on a cliff. Considering the potential for further caves or recesses on Kaimear Island, it is estimated that there are still several locations of rock art sites to be identified in the future.

The rock art is located in a niche called by the local population the Kailean niche, located on a rock cliff near to the settlement. The observed rock art includes hand stencil, foot, and human figure motifs in a variety of styles, human face motifs both triangular and round, boat, sun, and animal motifs which include fish forms of fish, and various non-figurative motifs include patterns forming lines like nets, and other forms of unidentified motifs. Considering that this research was carried out through a very limited survey, in the future it requires more systematic and intensive further study. Besides, because of the potential richness of archaeological resources, the art rock on Kaimear Island should be followed up immediately through various management programs and dissemination of their importance to the population and local government. Also, given the threat of damage to rock art sites due to natural and human factors, in the short term, it is necessary to carry out activities by agencies related to cultural heritage management. Coordination between central and local governments, as well as with local communities should be formulated for site management, utilization and development programs, including registering rock Art Sites on Kaimear Island as a National Cultural Heritage Site, in order to achieve better attention from the central government. 


\section{ACKNOWLEDGEMENT}

The authors would like to thank the Head of the Balai Arkeologi Maluku, Drs. Deni Sutrisna, M. Hum for our assignment to research in 2018. In addition, the highest appreciation is also conveyed to Dr. M. Zein Nuhuyanan, Secretary of the Tual City Education and Culture Office for all the provided support and facilities. Our best gratitude also goes to Husein Hamzah Tukloy who always accompanied us and gave many conveniences during the research trip around the Kei Islands region. We would also like to express our highest appreciation to the Head of Kur Islands, Secretary of Kaimear Village, Lajuki Rettob and all Kaimear Village people who have helped and facilitated the implementation of this limited survey. We also thank for our colleague Marlon NR Ririmasse, M.A. for light discussions about the discovery of this rock art site.

$* * * * *$

\section{REFERENCES}

Arifin, K. (1992). Laporan Penelitian Lukisan Batu Karang di Indonesia: Suatu Evaluasi Hasil Penelitian. Depok.

Arifin, K., \& Delanghe, P. (2004). Rock art in West Papua. Paris: UNESCO Publishing.

Aubert, M., Brumm, A., Ramli, M., Sutikna, T., Saptomo, E. W., Hakim, B., ... Dosseto, A. (2014). Pleistocene Cave Art from Sulawesi, Indonesia. Nature, 514(7521), 223.

Ballard, C. (1988). Dudumahan: a rock art site on Kai Kecil, SE Moluccas. Bulletin of the Indo-Pacific Prehistory Association, 8, 139-161.

Bhattacherjee, A. (2012). Social Science Research: Principle, Methods, and Practices. Florida: University of South Florida.

BPS, K. M. T. (2017). Kecamatan Pulau-Pulau Kur dalam Angka. Langgur: Badan Pusat Statistik Kabupaten Maluku Tenggara.

Fage, L.-H. (2014). Matarombeo 2014. Prospection archéologique, massif de Matarombeo, Sulawesi Central, octobre 2014. Marseille: Le Kalimanthrope.

Fage, L.-H., \& Chazine, J.-M. (2009). Bornéo: la mémoire des grottes. Lyon: Fage Éditions.

Fauzi, M. R. (2016). Beberapa Hasil Awal Penelitian Arkeologi di Kawasan Kars Bukit Bulan, Sarolangun. Siddhayatra, 21(1), 1-12.

Gonthier, E., Budiman, Djami, E. N. I., \& Simanjuntak, T. (2013). Art pariétal dans la baie de Triton, sud-ouest de la Papua-Barat: Etudes sémiologiques des tracés pariétaux archéologiques. Les Amis Du Muséum National D'histoire Naturelle, 256, 54-57.

Intan, F. S., \& Istari, R. T. M. (1995). Laporan Penelitian: Geologi dan Arkeologi Situs Gua Kepulauan Kei Kecil Kabupaten Maluku Tenggara Propinsi Maluku. Ambon.

Kealy, S., Wattimena, L., \& O’Connor, S. (2018). A Geological and Spatial Approach to Prehistoric Archaeological Surveys on Small Islands: Case Studies from Maluku Barat Daya, Indonesia. Kapata Arkeologi, 14(1), 1-14.
Kosasih, E. A. (1999). Notes on Rock Paintings in Indonesia. In Aspek-Aspek Arkeologi Indonesia. No 23. Jakarta: Pusat Penelitian Arkeologi Nasional.

Lape, P. V. (2000). Political Dynamics and Religious Change in the Late Pre-colonial Banda Islands, Eastern Indonesia. World Archaeology, 32(1), 138-155.

Lape, P. V. (2002). Historic Maps and Archaeology as a Means of Understanding Late Precolonial Settlement in the Banda Islands, Indonesia. Asian Perspectives, 41(1), 4370.

Lape, P. V., Aziz, F. A., Ekowati, D., Huff, J., Handoko, W., Huwae, A., \& Zenobi, L. (2017). Reframing the Island Southeast Asian Neolithic: Local vs regional adaptations. In B. Prasetyo, T. S. Nastiti, \& T. Simanjuntak (Eds.), Austronesian Diaspora: A New Perspective (pp. 65-76). Yogyakarta: Gadjah Mada University Press.

Leihitu, I., \& Permana, R. C. E. (2018). Looking For a Trace of Shamanism, in the Rock Art of Maros-Pangkep, South Sulawesi, Indonesia. Kapata Arkeologi, 14(1), 15.

NGA. (2018). Sailing Directions (Enroute) New Guinea. Fourteenth Edition. Springfield: National GeospatialIntelligence Agency.

O'Connor, S. (2003). Nine New Painted Rock Art Sites from East Timor in the Context of the Western Pacific Region. Asian Perspectives, 42, 97-128.

O’Connor, S., Louys, J., Kealy, S., \& Mahirta. (2015). First Record of Painted Rock Art near Kupang, West Timor, Indonesia, and the Origins and Distribution of the Austronesian Painting Tradition. Rock Art Research, 32(2), 193-201.

O’Connor, S., Mahirta, Kealy, S., Boulanger, C., Maloney, T., Hawkins, S., ... Louys, J. (2018). Kisar and the Archaeology of Small Islands in the Wallacean Archipelago. The Journal of Island and Coastal Archaeology, 1-28.

O'Connor, S., Mahirta, Tanudirjo, D., Ririmasse, M., Husni, M., Kealy, S., ... Alifah. (2017). Ideology, ritual performance and its manifestations in the rock art of Timor-Leste and Kisar Island, Island South East Asia. Cambridge Archaeological Journal, 28(2), 225-241.

Oktaviana, A. A. (2016). Advanced Rock Art research in Muna Island, Southeast Sulawesi. In Makassar (Ed.), The Archaeology of Sulawesi: an update.

Oktaviana, A. A., David, B., Sue, O., Budianto, H., Suryatman, Wibowo, ... Fahri. (2016). Hand Stencils With And Without Narrowed Fingers at Two New Rock Art Sites in Sulawesi, Indonesia. Rock Art Reseach, 33(1), 32-48.

Oktaviana, A. A., Lape, P., \& Ririmasse, M. N. (2016). Recent Rock Art Research on East Seram, Maluku: A key site in the rock art of West Papua and South East Maluku. In In The 2nd SEAMEO SPAFA International Conference on Southeast Asian Archaeology. Bangkok.

Permana, R. C. E. (2005). Bentuk Gambar Telapak Tangan Pada Gua-Gua Prasejarah di Kabupaten Pangkajene Kepulauan, Sulawesi Selatan. Wacana, 7(2), 161-174.

Ririmasse, M. N. (2006). Aspek-aspek kronologi arkeologi kolonial di Pulau Kisar. Berita Penelitian Arkeologi, 2(1)

Ririmasse, M. N. (2007). Tinjuan Kembali Seni Cadas di Maluku. Kapata Arkeologi, 3(4), 1-21.

Ririmasse, M. N. (2010). Migrasi dalam Studi Arkeologi di Kepulauan Maluku: Sebuah Pengantar. Kapata Arkeologi, 6(11), 76-92.

Ririmasse, M. N. (2013). Survei Arkeologis di Kawasan Halmahera Bagian Tengah. Kapata Arkeologi, 9(1), 1328.

Ririmasse, M. N. (2016). Arkeologi Kepulauan Tanimbar Bagian Utara: Tinjauan Potensi di Pulau Fordata dan Pulau Larat Maluku Indonesia. Kapata Arkeologi, 12(1), 43.

Röder, J. (1938). Felsbilder auf Ceram. Paideuma, 1(1), 19-28. 
Salhuteru, M. (2009). Situs Lukisan Cadas di Desa Wamkana Kabupaten Buru Selatan. Kapata Arkeologi, 5(8), 69-77.

Setiawan, P. (1994). Gambar Cadas Dunwahan, Tinjauan awal isi-wimba berdasarkan posisi sebenarnya di cadas. Bandung: Institut Teknologi Bandung.

Setiawan, P. (2015). Pendahuluan. In R. C. E. Permana (Ed.), Gambar Cadas Prasejarah di Indonesia. Jakarta: Direktorat Pelestarian Cagar Budaya dan Permuseuman, Kementerian Pendidikan dan Kebudayaan.

Simanjuntak, T., \& Oktaviana, A. A. (2012). Laporan Penelitian Arkeologi: Perjalanan Panjang Peradaban $O K U$. Jakarta.

Spriggs, M., \& Miller, D. (1988). A Previously Unreported Bronze Kettledrum from the Kai Islands, Eastern Indonesia. Indo-Pacific Prehistory Association Bulletin, 8, 79-89.

Sudarmika, G. M. (2000). Laporan Hasil Penelitian Arkeologi Bidang Arkeometri di Kec. PP. Babar Kabupaten Maluku Tenggara Barat. Ambon.

Sudarmika, G. M. (2001a). Laporan Penelitian Arkeologi di Pulau Lakor Kecamatan Lemola Maluku Tenggara Barat. Ambon.

Sudarmika, G. M. (2001b). Laporan Penelitian Arkeologi di Pulau Leti Kecamatan Lemola Maluku Tenggara Barat. Ambon.

Sulistyarto, P. H., Oktaviana, A. A., Adhityatama, S., Ramadhan, A. S., Ariadi, A. P., Mahmud, I., \& Prameswari, Y. (2014). Laporan Penelitian Arkeologi: Penelitian Arkeologi Maritim Hunian Prasejarah dan Lukisan Cadas di Kepulauan Misool, Kabupaten Raja Ampat, Provinsi Papua Barat. Jakarta.

Suryanto, D. (1997). Laporan Penelitian: Hasil Penelitian Bidang Prasejarah di Kecamatan Buru Selatan, Kabupaten Maluku Tengah, Propinsi Maluku. Ambon.

Whitley, D. S. (2005). Introduction to Rock Art Research. California: Left Coast Press inc.

Wright, D., Denham, T., Shine, D., \& Donohue, M. (2013). An Archaeological Review of Western New Guinea. Journal of World Prehistory, 26(1), 25-73. 